\title{
Beyond Commerce: The Fashion Magazine as Art and Theory Communication and Culture MA Project Paper
}

Submitted by: Truc Nguyen Submitted on: April 30, 2007 Project Committee Members:

Michael Prokopow, Communication and Culture Faculty Member (Ryerson) David Skınnerd, Communication and Culture Faculty Member (York) Lu Ann Lafrenz. Fashion Faculty (Ryerson) 
"I don't care about photography. I don't want art. I want to sell frocks!"

- Fashion Editor Diana Vreeland (Qtd. in Angeletti 188)

What are the defining characteristics of a fashion magazine? Can the genre exist outside of a commercial context? Are aesthetics and theory alone enough to create something worth reading? Taken outside of the context of consumer culture, what is its difference from "art" publications? These are the questions central to this project, entitled "Beyond Commerce: The Fashion Magazine as Art and Theory." The project visually and critically examines some of the tensions and contradictions between fashion and art in general terms, and it explores specific topic and debates within contemporary fashion theory through a review of the current academic and cultural literature on the business and art of fashion and magazines, interviews with fashion editors, and the creation of a magazine proof entitled Deeply Superficial.

In his 2005 book Fashion Magazine, created to accompany an exhibition of the same name at Le Bon Marché in Paris and Rockett Gallery in London, British photographer Martin Parr explored these very same themes by single-handedly photographing and publishing an entire fashion magazine, including a masthead and advertisements. What interests Parr about the project is playing conceptually with the "standard ingredients of any fashion magazine" (32) and the fact that:

Some of the shoots feature models, some are people who were cast in the street. sometimes you cannot tell the difference. Some shoots resemble documentary, some look more like fashion, they can even look like art! What is exciting is that it is difficult to tell the difference. The traditional boundaries of these worlds are slipping away and I am enjoying these new fusions. (11)

Parr was far from the first artist to explore the conceptual boundaries of the genre. however. For several months in 1874, the French poet Stephane Mallarme undertook a similar project and independently wrote, edited and published a fashion magazine entitled La Dernière Mode. 
Through the use of a variety of male and female pseudonyms and characters, Mallarmé explored divergent and competing facets of the fashion system, gives dress advice to readers and deconstructs social etiquette and fashion trends on a biweekly basis. By doing so, he was able to consider fashion, "its rules, philosophy and rhetoric of persuasion...from the inside," seriously recognizing the genre's construction while at the same time parodying it (Mallarme 910).

While La Dernière Mode was a short-lived endeavor, Mallarmé's idea of analyzing the components and idiosyncrasies of magazine publishing, magazines and the business of fashion itself through the creative process rather than mere theory or critique is central to the conception of the "Beyond Commerce" project, which also explores and deconstructs fashion magazines, fashion theory, and fashion itself through the practice of editorial publishing-its customs, processes and restraints-rather than just through theory alone. Deeply Superficial, however, forgoes the features and front-of-book sections typical within the genre, and focuses exclusively on fashion editorial photography because of practical considerations as well as fashion photography's richer relationship to fashion theory. In fact, I would argue that fashion editorials are the most conceptually rich and ideologically problematic pages of any publication, and are expressive of each magazine's personality. Although magazines such as Vogue and Harper's Bazaar are also read for informational purposes, the fashion photographs and accompanying text are what defines and distinguishes each magazine to the reader, and where fashion magazines differ from general women's interest publications. Fashion photographs are images, either painstakingly constructed or captured on the spur of the moment, that are intended to showcase fashion products, abstract notions of style, and "the relationships between clothes. wearers and contexts" (Craik 93). These images can be simple and pragmatic, as is the case with catalog or stock photography, or highly symbolic and deliberately "fabricated to produce and evoke synesthetic sensations" (Mandoki 601). 
Beginning with a definition of the objectives and key themes of the project, as well as its relationship to the Communication and Culture Program, this essay explores and articulates the creative process as well as the final product's ability to reconsider the fashion magazine genre. I provide an overview of the methodology and relevant literature on fashion magazines, and discuss in detail the theoretical basis for each editorial component of the magazine. "Beyond Commerce" is a project informed by a variety of interests, readings, and professional experience, and the discussion of the production process will consider the challenges faced, rationale for decision-making, technical and pragmatic production issues, and the effectiveness of each component of the final product. The findings will be contrasted with both the theoretical literature on fashion magazines and interviews conducted with influential fashion editors in Canada and the United States. Finally, I will review the lessons learned and conclusions made through completion of the project, and its potential contribution to theoretical knowledge as well as professional practice.

The objectives of this project are two-fold, to explore the mechanical and cultural constructions of a fashion magazine, and consider the contemporary state of fashion theory through the creation of fashion editorials. Without advertising, and with its ambivalent relationship to consumer culture, this magazine will instead explore our relationship to dress from a theoretical and creative standpoint. Without the incentive to create a 'buying mood', "Beyond Commerce" aspires to critically address both the shortcomings and inherent appeal of the genre, and test its possibilities outside of the normative format.

As a high quality, full-colour "fashion" magazine that includes over 40 pages of text and photography featuring editorials inspired by and reflective of contemporary fashion theories, Deeply Superficial mimics as precisely as possible the genre's aesthetic characteristics and indicators. Each editorial in the magazine is inspired by, but not limited to, specific writings and debates within fashion academia and consumer cuiture at large. The intersection between globalization. street fashion and David Muggleton's theory on youth subcultures; Thorstein 
Veblen's writings on conspicuous consumption as related to 'logomania', branding and the problem of 'fakes'; Walter Benjamin's 'The Work of Art in the Age of Mechanical Reproduction" as applicable to mass market retailers' constant knocking off of designer fashions (recognizably copying a design or pattern but including enough differences to avoid legal infringement), the difference between high and low fashion, and the impact on fashion as art; Ted Polhemus's idea of 'anti-fashion' or constancy in design as integrated within the fashion system and its manifestation through various price points; and Mike Featherstone's eclectic and ahistorical 'postmodernism' and the cyclical fashion system's effect on dress and history are themes that are explored in the magazine. At the same time, the magazine aims to consider the ability-or inability-of fashion editorials and publications to communicate narrative and theoretical information, the potential distinctions between art and fashion editorials, and whether the promotion of consumption and consumer culture is an inherent aspect of the genre. As Diane Crane writes in Fashion and its Social Agendas, today "fashion, as presented in fashion magazines, has several diverse and inconsistent social agendas" (294). This project is interested in what this agenda might be, as well as the role of the editorial within consumer culture at large. What are the relationships between fashion magazines, advertisers, and readers? How do these relations affect the tone and content of what is published or, for that matter, what is seen and read? A noncommercial fashion magazine such as Deeply Superficial highlights the compromises and tensions that mark the genre, while never being truly removed from commercial interests entirely because fashion and its objects are still fetishized throughout the book.

Ultimately, "Beyond Commerce" offers a novel application of theory to actual practice, or actual practice as 'enabled', offering a visual as well as theoretical exploration into the components and functions of the fashion magazine genre. The project uniquely focuses on the creative process, whereas most existing magazine studies are simply concerned with the social 
effects of these publications and their function within capitalist economic systems'. Further, it is rare to find academic work that has been conducted by someone who understands the financial and practical constraints and issues of the publishing industry as well as the intricacies of the fashion industry. In that sense, the project offers an insider's perspective and realistic critique of the genre that goes beyond theory and onto the set or into the design software. Finally, the project intends to remind industry professionals that there is a large and relevant body of theoretical work from which they may draw inspiration for their professional practice. For although the project is not intended for a professional audience, but rather an academic one, its explorations of theory and commerce go into the heart of the dilemma of modern publishing and speak to the fine line that editors must walk (and sometimes cross).

As a project which has professional as well as academic merit, "Beyond Commerce" is a relevant example of the interdisciplinary, practical approach to learning ${ }^{2}$. The first magazine that focused on the subject of fashion, Le Mercure Galant, was first published in France in 1763. However, it was the American periodical Godey's Lady's Book which truly defined the characteristics of the genre from its inception in 1830 , offering women fashion patterns alongside fiction, editorials and illustrations on a consistent basis (Angeletti 4). Today, as a central communication medium within contemporary culture, fashion magazines are an important and relevant subject for academic research, and one which would benefit from a multidisciplinary analysis. Despite discussions throughout the hallowed halls of academia about the advent of the Internet and the demise of traditional publishing, women's fashion magazines still sell millions of copies monthly in Canada and throughout the world. As such, these publications perform an important social and ideological role within our culture. Today it is not

\footnotetext{
'Examples of effects or consumer-oriented research are Dawn Currie's Girl Talk: Adolescent Magazines and their Readers, Diane Crane's "Gender and Hegemony in Fashion Magazines: Women's Interpretations of Fashion Photographs," and Leslie Rabine's "A Woman's Two Bodies: Fashion Magazines, Consumerism, and Feminism."

${ }^{2}$ The Communication and Culture program at Ryerson and York universities embraces. According to its official website, the program aims to promote the "application of theory and research to contemporary issues and practices in communication and culture" ("About the Programme").
} 
unusual to have conceptual and theoretical frameworks trump the business of showing consumer products in editorial spreads in high-end glossies and avant-garde independent magazines. In other words, in some instances the clothing in fashion photography has become subordinate to the concepts, lifestyles, state of mind, and moods presented ${ }^{3}$ (Kismaric 20). However, the underlying and unspoken assumption is that these publications are all in the business of selling consumers to advertisers, in the manner of Dallas Smythe's theory on the audience commodity. Dawn Currie notes, "Mass Marketed magazines must provide issues of interest and relevance to readers... but at the same time they must provide a "buying mood"' (94). Because magazines serve multiple audiences, including readers and advertisers, their content is necessarily shaped to please these groups while potentially compromising both groups' interests to some degree. It is critical to examine, then, the construction of this medium and how its form and content can be reconsidered and even subverted.

"Beyond Commerce" aspires to critically address both the shortcomings and inherent appeal of the fashion magazine genre, and to test its boundaries outside of the normative format. In order to create such an ambitious creative project, and imbue it academic as well as cultural relevance, the methods used in the background research process must be accordingly complex and relevant. Although the project is technically a creative and aesthetic endeavor, this essay and the prototype publication, Deeply Superficial, are based on non-experimental postpositivist research conducted using several methods including a literature review of the relevant theoretical debates and the magazine industry's history and practice, and open-ended semistructured "elite" interviews with influential fashion editors. Furthermore, "Beyond Commerce" is greatly influenced by and interested in the creative and technical steps involved in fashion magazine publishing, including conceptualizing the desired editorial images, acquiring the

\footnotetext{
"For example, in 1998 Mikael Jansson photographed a spread for the progressive Dutch magazine entitled "Homosapiens Modernus." There were no clothes featured in any of the 40 pages, although fashion credits were given. Essentially, the point was to prove that "a fashion photograph is defined as such only by a credit in the corner of a page"(Kismaric 20 ).
} 
appropriate apparel, accessories, and props, and sourcing available and affordable talent. Most of the on-figure photo shoots required hours of planning and legwork, and a talented and conceptually relevant photographer, make-up artist, and model who will each work for free in exchange for creative rights and an addition to their portfolio. At the end of the process, the layout and printing stages also provided both logistical challenges and educational opportunities.

At the beginning of the project, I chose to use for the project what Johnson and Reynolds define as a non-experimental research design, which is characterized by one or more of the following: "[the] presence of a single group, lack of control over the assignment of subjects to groups, lack of control over the independent variable, or inability to measure the dependent variable before and after exposure to the independent variable occurs" (74). Because the choice of editorials analyzed and editors interviewed for this project are based on topical relevance and availability, rather than random selection or assignment, the project would be categorized as non-experimental. Furthermore, because the end result is a broad creative project, there are numerous "independent" and "dependent" variables that will be examined, some of which cannot be measured, or their relationships triangulated and defined. The use of elite interviews is a common research method in political academic work, but in this case was also helpful in providing guidance and direction for "Beyond Commerce." Fashion editors at American Vogue and Canadian Flare and Fashion magazines were interviewed for their thoughts on the creative and commercial aspects of the editorial process, the constraints of the medium, and challenges to the genre at large. Darren Lilleker suggests in his writing on elite interviews, which can be broadly defined as those conducted with individuals "with close proximity to power" in a particular field, that they are an excellent method for "getting inside the subject" (207). Although they can be difficult to interpret and have "severe limitations" in terms of reliability and need to be triangulated or reinforced by other forms of data, these interviews offer 
unparalleled access to "insights into events about which we know little: the activities that take place out of the public or media gaze, behind closed doors" (Lilleker 208).

In contrast to closed interviews, open-ended interviews are "provisional" and questions "may be abandoned, altered, and tried again" rather than fixed, allowing for follow-up queries and personalization in the interview process (Hammer and Wildavsky 57). This flexibility is useful as well as necessary, as each respondent will have different things to say and experiences to draw upon and the ability to adjust the questions accordingly is important. An excellent related example on interviewing the periodical publishing elite can be seen in Melissa Milkie's 2002 article in the journal Gender and Society, entitled "Contested Images of Femininity: An Analysis of Cultural Gatekeepers' Struggles with the 'Real Girl' Critique." In this article, Milkie looks at the struggles related to teen magazine portrayals of girls by "examining how cultural gatekeepers respond to girls' vocal critique of inauthentic media images" (839). The research methodology included a literature review and interviews with 10 editors at two national magazines on the issue of depicting "real girls" in mass media products. Milkie writes that:

The interviews concerned how producers create products for their adolescent audience. Questions for editors centered on three general areas-how they understood and framed their product, the daily operations of choosing and selecting ideas and images both individually and as an organization, and how they process requests and criticism from their readers. (846)

Milkie's study demonstrates that valuable insights can be found by simply looking at the encoding and creative process of media-making, although most magazine-related research today is interested in the ideological effects of media products, or how they are interpreted and decoded by the audience.

The "Beyond Commerce" project was undertaken from November 2006 to April 2007, beginning with the background research and literature review and continuing with the openended interviews with fashion editors. The interviews were conducted in person and over the 
phone, using a set list of questions although because the format was open-ended, the interviewer was able to ask personalized follow-up questions for clarification and elaboration. The results of the interview were very helpful and educational, and many of the respondents corroborated each other's responses, although it was clear that the status and budget of the publication for which they work also played an important differentiation role. In his work on interviewing political elites, Lilleker writes that:

Interviews do provide insights into events about which we know little: the activities that take place out of the public or media gaze, behind closed doors. We can learn more about the inner workings of the political process, the machinations between influential actors and how a sequence of events was viewed and responded to within the political machine. (208)

Similarly, interviewing the fashion media elite allowed me to better understand the magazine production process from their point of view. For example, Flare magazine associate fashion editor Nicole Forbes explains in her interview on 28 February 2007 in Toronto that all of the stories in the magazine begin, simply enough, from what is shown on the runways in Paris, New York and Milan. According to Forbes, the "major trends that flare up" are then picked apart by the editors to "to be the starting points for all of [the] 'fashion wells'" in Flare over the following six months, until the next season's shows are presented. In a telephone interview with Michal Saad, the associate fashion editor at Vogue magazine, on 24 January 2007 in New York City she reveals that perhaps it is actually "a lot harder to create a 'fashion' picture than it is an 'art' picture," because with the latter there are many more restrictions in terms of "the credits [garments] that you have to get in" to please advertisers, and everything has to be "featured in a very clear way" so that the reader is serviced as well. There are important issues that editors must consider and balance each day during the creative and technical process of magazine production that affect the end product. The idea that each issue of a publication is a collaborative effort that has gone through numerous alterations and transformations by 
competing forces as well as chance is compelling considering how the final product is analyzed for meaning and defirition by researchers such as Crane and Currie $^{4}$. These interviews provide an inside look at the way these editors see their work, and the struggles and issues that they face from concept to creation.

The primary drawback to conducting these elite interviews was access and timing. Unless I personally knew an editor, it was impossible to arrange a meeting with them because of their incredibly hectic schedules. This was a methodological problem which Robert Phillips identified with elite-based research, nothing that issues of "access and 'gatekeeping"' are the norm depending on "the nature of the elites themselves, the actual timing of the interviews and their relationship with the policy process and finally, the sensitivity of the issue being researched" (8). Even after using personal connections, many of my phone calls and emails for interview requests went unanswered, and ultimately the scope was broadened to include interviews with fashion editors at women's magazines as well as those at fashion magazines.

While conducting the interviews, I also planned and produced the photo shoots for the project, which was a difficult task despite my familiarity with the process and connections within the fashion industry and with young artists in the community. "Same Same, But Different" was photographed primarily while I was traveling in Southeast Asia in November and December 2006, and required little planning as I simply photographed young women on the street whose dress I found unique or eye-catching during my travels through Thailand, Singapore, Malaysia and Vietnam. The process was much more organic than calculated, relying on chance encounters and timeliness. For street-fashion photography, often the criteria for what makes a compelling photography subject is very fluid and the decision-making process is heavily reliant

\footnotetext{
'Works such as Crane's Fashion and its Social Agendas (2000) and Currie's Girl Talk (1999) have been quite influential sociological looks at the magazine publishing industry. However, they focus on the effects rather than the construction of the genre.
} 
on the 'eye' of the photographer ${ }^{5}$. On the same trip, I purchased the counterfeit fashion goods for "Logomania," making sure to acquire a variety of branded products in different accessory categories. The still-life photography was a simple process because of the desired look, which was homespun and unflattering in deliberate contrast to many glossy magazines' fetishization of the fashion accessory.

More financially and logistically demanding were the other three shoots, all of which were photographed on location with professional hair and make-up artists, semi-professional photographers and their assistants, and models from agencies such as Next, Elite and Ford. Through the process of planning these shoots, many challenges that editors spoke about during the interviews became ones that had to be overcome, including a lack of financing, scheduling conflicts, poor weather, and access to locations, clothing, and talent. Even at Flare, Canada's top fashion magazine, Forbes admits that improvisation on set is not unheard of, and their vision for a fashion story is always changing, because normally they will "get a third" of the samples that they request from fashion houses due to competition from other publications. Of course, working without the budget or resources of an actual publication behind me, I was forced to purchase and later return clothing for these photo shoots -severely limiting the number of garments and brands that could be incorporated into the photographs. As well, because everyone involved worked for free on the magazine, I had to take in consideration their needs as well as mine when making aesthetic decisions about hair, make-up and location. For example, the images featuring colourful, exaggerated make-up in "The Modern Uniform" and "History Now" had to be balanced with more neutral looks so that the model would have at least one portfolio-appropriate 'tear' (or picture) in exchange for the day's work.

\footnotetext{
${ }^{5}$ The Japanese photographer and editor Shoichi Aoki writes in the Foreword of Fruits that "What is important are one's thoughts and the ability to express them, one's life and its relationship to the environment. When such elements are combined they create a sculpture. This sculpture I call street fashion."
} 
The final step before the completion of "Beyond Commerce" was the graphic design and layout component of magazine publishing. Although I was familiar with Adobe InDesign, Illustrator and Photoshop, this 'art department' component required that I to learn not only the basics, but the 'tricks' for each program. The order of the pictures and stories, and the role and placement of text had to be considered for each editorial. Fonts, graphics and colours are other important components of any publication, affecting how the reader will understand any particular story and perceive the magazine as a whole.

With all these separate yet equally important methodological steps, the project is bound by and built on a rich body of academic literature on the themes of fashion, art, and media. There are a number of theoretical and academic writings related to the project, on topics such as but not limited to: the relationship between art and fashion, the ideological role of fashion magazines, conspicuous consumption, postmodernism, reproduction and authorship, antifashion, and subcultures. Therefore, a literature review of the relevant theoretical debates and the magazine industry's history and practice is an important overarching step in the project's methodology. For the project, I examined the classic writings and themes on which each editorial was based, such as Thorstein Veblein's 1899 book, Theory of the Leisure Class, as well as any secondary literature expanding on or critiquing these pieces and themes. As well, 1 considered a large number of existing texts on the business and cultural role of fashion, women's and fashion magazines, the publishing industry, fashion photography, and magazine design and production. .

Writing on fashion magazines, theorists such as Leslie Rabine and Katya Mandoki argue that their cultural role of has changed greatly in the past few decades. These publications no longer serve "as a source of necessary information...to protect us from the danger of looking passé or déclassé"; rather, they are now "a source of fascination and guided imagination," connecting us to the constantly changing fashion system (Mandoki 607). In "More Than Just a 
Fashion Magazine," Brian Moeran explores many of these questions about role of the medium, asking:

What are the purposes of a fashion magazine? To inform readers of the latest fashions, of who is wearing what in the entertainment world and where they may find the clothes shown in its pages every month? To provide a venue for advertisers... so that the magazine's publisher can stay in business and make a profit? (725)

In order to answer this question, Moeran conducted over 40 open-ended interviews with editors, art directors and publishers at a variety of publications worldwide. Because fashion magazines are "both cultural products and commodities," any analysis must recognize both their cultural influence and role, and inherent involvement "in capitalist production and consumption at national, regional and global levels" (Moeran 727). Moeran explains that there are very specific formulas and formats that most fashion magazines follow in both their content and look; for example, "photographs should be edited in such a way that the clothes shown fill between 60 and 70 percent of the page, with background amounting to 30 , at most 40 , percent" (730). Although most of this article's findings are more descriptive than analytical, the author astutely recognizes the objectives underlying and controlling the structure and content of these publications. According to Moeran, fashion magazines "impose stability on the instability" of a fashion system "marked by continuous change," connect the various stakeholders of the fashion industry to each other and the audience, and interest and educate readers on fashion products and brands (736). It is these objectives which drive all editorial decisions, and therefore the specific look and content of each publication.

The fashion well (or the series of photographic 'stories' in the middle of the 'book' that use "visual images to illustrate some new fashion trend") is considered the most important and definitive editorial component of any fashion publication (Moeran 730). Accordingly, the fashion photographs that appear in these pages are the focus of study for the project and the primary component of the "Beyond Commerce" magazine prototype. Fashion photographs have been a 
defining component of women's magazines since improved lens technology allowed for faster shutter speeds and Edward Stichen's images appeared in Art de Decoration beginning in 1911 (Tarantino 1). For a long time, fashion photography was a conservative field which aimed to simply "illustrate the work of renowned designers and to use flattering poses and settings to highlight the attractiveness and originality of the clothing" rather than provide any true inspiration for the reader (Lipovetsky, "More Than Fashion" 8). In contrast, contemporary fashion photography is a field which is increasingly diverse and eclectic, with the top established photographers and younger emerging artists experiencing unprecedented freedom of expression and "creative autonomy" (Lipovestky, "More Than Fashion" 9). As Ulrich Lehmann explains in "Fashion Photography", although the genre is highly ideological and predicated on the support of commodity culture, "the gesture of the fashion photographer is actually free to a surprising degree. With the loss of the descriptive requirements of fashion images and the ascendancy of an artistic representation of garments, perspectives on fashion ceased to be prescribed." (13).

Of course, it would be misleading to suggest that all-or even most-working editorial photographers now have the ability to create whatever they would like, regardless of the commission of the magazine or newspaper, and work entirely outside of the control of fashion, market, casting editors and directors, and fashion stylists. But instead of merely capturing a "timeless moment," photographers are now much more free to "represent a moment in time" in a narrative whose authorship they can stake a claim on (Kismaric 12). According to Michal Saad at Vogue, rather than creating images to please an editor or art director, fashion photographers today have more influence on set and collaborate with these decision-makers to create images that are compelling for all involved parties. As Lipovetsky explains in "More Than Fashion," because of this newfound freedom, the genre has been able to incorporate more serious but less commercial themes, stimulate "public debate and theoretical discussion," and ultimately be considered in the arena of 'art' (10). 
Dennis Freedman, former Creative Director of $W$ magazine and Vice Chairman of Fairchild Publications, believes that to the viewer "The only discernible difference between the fashion pictures that appear in the magazine and the art pictures sold by the gallery-besides format and context-is that one has fashion credits and the other doesn't" (qtd. in Kismaric 134). However, if culture is traditionally divided into the ranks of high, middle and low, then art's status is at the highest ranking, affecting the way we consider it in relation to craft, as well as "material consequences" such as "the policies and practices of educational and arts institutions, galleries and museums" (Walker 6). Fashion, on the other hand, has traditionally been considered a feminine, frivolous, and commercial enterprise by academics and cultural theorists alike.

At the same time, small but influential independent magazines such as Dutch, Tank, and *Surface have fostered a hybrid of art and fashion features and contributors within their pages, and served to bridge the gap in between these fields. In fact, because of their niche demographic and significantly fewer publisher constraints ${ }^{6}$, they have been able to foster "an artistic approach to fashion" and create editorial spreads that "were born not from trends seen on the runway, but rather from a conceptual beginning, either a literal, cinematic, or psychological impetus that made for a compelling story" (Kismaric 20). As Paul Jobling explains in Fashion Spreads: Word and Image in Fashion Photography since 1980:

Whereas for Vogue the issue has always been how to harness the photographer's creative autonomy to the demands of advertisers and designers alike, alternative magazines like The Face have enjoyed relative freedom in both their choice of subjectmatter and the way that they represent fashion. (35)

This relative freedom has allowed independently published titles such as The Face and Vissionaire to introduce numerous design, photographic and typographic innovations into

\footnotetext{
${ }^{3}$ This point was emphasized by most respondents during the elite interview process. Several of the fashion editors interviewed, who worked for magazines published by large corporate entities, confirmed that the restraints were fewer for their peers working at independent or "indie" publications. (See appendix)
} 
magazine publishing in the last few decades. For example, when Neville Brody included "colourful, asymmetric typography in different fonts and weights" to his layouts for The Face in the early 1980s, it was a unique and revolutionary design decision (Jobling 38). Now, such experimental and postmodern page designs can be found on most magazine racks.

Within the magazine publishing industry, the 'art' versus 'fashion' debate has resulted in some blurring of the line between 'editorial' work and 'artwork'. Renowned fashion photographers are exhibiting their work at art galleries and museums, and big-budget magazines such as $W$ regularly collaborate with artists to create unique imagery and installations. In fact, in the late 1980s when the avant-garde Japanese brand Comme des Garçons created a 'fashion magazine' entitled Sixth Sense to showcase its designs, the art critic Glenn O'Brien noted that the company "has created one of the great art magazines of our time, except that it's not really an art magazine, it's a clothing catalogue" (qtd in Townsend 96). What this all means, ultimately, is that the "boundaries between art and fashion journals" and those between 'art' and 'fashion' photography are constantly being challenged and redefined as the definition of art shifts (Townsend 96).

If the contemporary notion of art is shifting and morphing, then so is the social role and public image of fashion and dress. As defined by fashion writers such as Ted Polhemus and Joanne Entwistle, 'fashion' is "a special system of dress, one that is historically and geographically specific to western modernity" which is predicated on constant change and the consumption of material goods (Entwistle 43). It is a theoretically rich and truly multidisciplinary subject of study, and one which is riddled with controversy and debate. For example, fashion is still considered by many critics as "Irrational, capricious, fickle, unpredictable" and, ultimately, an insubstantial object of study (Vinken 3). In "The Self As Image," Llewellyn Negrin explains that the "frivolity" of fashion and its dependence on constant change is what exasperates its critics, including the French theorist Jean Baudrillard (114). In fact, as early as the $18^{\text {th }}$ century Wolfgang Goethe wrote in "On Art and Craftwork" that "the two realms [of art and fashion] 
should be absolutely separate from one another," comparing a fashion designer to "a mere craft laborer for some astute manufacturer" rather than an artist (139).

Since the 1980s, however, fashion has been much more favourably recognized by academics and artists alike "as a worthy form of cultural expression, [even] making its entrée into distinguished museums" (Müller 14). The physical, linguistic and aesthetic boundaries between the two areas have all but faded away "so that it was no longer possible to distinguish which belonged" in the gallery and which in the boutique (Müller 14). Still, the 'art' and 'fashion' debate is live and well even today, as Chris Townsend explains, "Art is understood to transcend the ephemeral gratification of fashion and offer instead sustained and weighty meditations on eternal verities. To admit fashion as equivalent is to endanger the discourse by which art established its cultural superiority." (18).

The central issue of this debate-and the one most relevant to any consideration of the fashion magazine-is whether something so commercially driven could at the same time have artistic merit. When critics such as Christopher Breward believe that there is a "conspiracy of taste and compromise" and "a magazine [will go] to great lengths to make bad clothes look good, because the designer is advertising heavily in its pages" ("Culture" 226), how can they consider objectively the artistic merit of the photographs and stories in that magazine?

This apparent divide between artistic merit and commercial intentions is set aside within the "Beyond Commerce" project, because the magazine is neither advertising-funded nor financially-minded. For Deeply Superficial, the aim is to create a compelling, aesthetically attractive fashion magazine whose foundation lay in fashion theory and conceptual thinking rather than commercial interests. Normally, in order to analyze fashion images, one must consider the underlying codes, signs and signification. Semiotics, or the study of signs, is a useful way to consider the way that fashion products and magazines are imbued with meaning and can be understood by the reader. The Swiss linguist Ferdinand de Saussure s branch of semiotics, or Saussurian structuralism, argues that signs can be divided into two parts, the 
signifier and the signified. A signifier is simply "a sound or object that calls to mind a concept or signified" (J. Berger 36). Interestingly, the relationship between the two parts -signifier and signified-is learned, and in fact "arbitrary or conventional" rather than natural (J. Berger 36). Codes are a way to make sense of signs, the "systems of conventions that we are taught or pick up from our culture" to help us interpret the meaning of signifiers (J. Berger 39). In the example of fashion, an item of dress can be considered a signifier of the wearer's social identity or social status, which would be the signified. Of course, if this relationship is arbitrary, the relationships that are inferred or imbued provide much room for observation and critique ${ }^{7}$.

In attempting any analysis, it is important to understand what the visual signs might signify about the editor and photographer's intentions, and what visual and other non-verbal cues they may have deliberately placed in the editorial to connote and denote specific statements and ideas. Examples would be to look for the use of "correlative sign-work," which is when one aspect of an image is juxtaposed with another in order to create or associate specific meanings, and note the "major referrent systems employed". by the magazine that denote how these images are meant to be understood (Ball and Smith 52). With the creation of this prototype fashion magazine, one can create the codes and referent systems and imbue each editorial with meaning, and deconstruct the theory in practice. Each 'story' in the magazine draws inspiration from a compelling fashion theory or debate, and the goal was to visually represent the issue to the reader without compromising the magazine's aesthetic appeal, so that a reader may enjoy to some degree any editorial with or without the theoretical background and explanation.

At once a fashion magazine and a deconstruction of the genre, Deeply Superficial includes only fashion editorials, very little writing, and zero advertisements. The project pushes the definition of a fashion magazine to its limits, by retaining most of the visual and sensory

\footnotetext{
${ }^{7}$ Joanne Finklestein, for example, discusses this issue in After a Fastion and concludes that "fashion is an arcane sign system, whose silent and ruthless protocols are used by some for their own purposes" (30) rather than system of signification where "stable meanings can be uncovered" (26)
} 
touchstones of main-stream publications while subverting editorial content and eliminating fundamental sections such as advertisements and feature stories. This was a conscious choice made for practical considerations of time and ability, as well as a theoretically-driven decision which privileges the importance of the editorial within fashion magazines. In "Fashion Photography," Lehmann writes that:

One of the most distinctive features of fashion photography is the narrative... The editorial in particular is fashion's characteristic device to invent and construct a story around clothing. This story can have a conventional linear syntax... or it can consist of repeated variations on a theme. (15)

It is these stories-which are also referred to by Norberto Angeletti, writing in In Vogue, as 'style essays'-that require the greatest amount of financial and creative resources from editorial staff, readers find most compelling, and help to distinguish the voice of one publication from the next. Of course, there are requirements and a normative format to these editorials, because their "aim is also to tell a story that is essentially insubstantial and ephemeral so as not to deflect attention from the clothes" while having a narrative that is "powerful enough" to draw the reader in and generate excitement as well as anticipation (Lehmann, "Fashion" 16). The inclusion of text is limited, since the caption simply "aligns the photo with the rest of the editorial and describes what should be clear from the photo anyway... reinforc[ing] our initial reading of the image and then shap[ing] our perception of its value as a commodity" (Lehmann, "Fashion" 17). Normally, text appears only as descriptive or identifying captions, and in the form of mood-enhancing quotations or short elaborations on the theme.

Each of the five fashion stories in Deeply Superficial, while following these general outlines, is at the same time distinctive because each takes as its starting point the concept and the narrative rather than the clothing or visual trend. Olivier Zahm's critique, then, that "even the best fashion photography is still in service of industry... [and therefore] destined for the trashcan along with the magazines in which it appears," is thus rendered less relevant (29). There is, 
within this magazine, no need to please advertisers or show specific fashions in flattering contexts. Of course, it can be argued that because Deeply Superficial still aims to present apparel and accessories appealingly while including theoretical concerns, it nevertheless continues to 'read' as a proponent of commercial culture and the consumption of the illustrated fashion goods. The magazine's first editorial showcases these contradictions by showing young women who participate in the system of fashion consumption but with some degree of freedom and personalization.

The facet of contemporary fashion theory explored in "Same Same, But Different" is the influence of globalization and international trade on "street" fashion and what David Muggleton's writings on youth subcultures. "Street style photography" is a fairly recent cultural phenomenon documenting exemplar or extreme styles of dress, finding its popular expression in the 1980's and 1990's in London through magazines such as $i-D$ and in Japan through Shoichi Aoki's FRUiTS magazine (Nylon Magazine 9). More recently, blogs such New York's The Sartorialist and the Facehunter in Paris have been transmitting the fashion choices of young urban dwellers throughout the world wide web, drawing hundreds of thousands of readers daily who are desperate to see what others are wearing in their own city and abroad.

Muggleton argues in Inside Subculture: The Postmodern Meaning of Style that the whole concept of youth subcultures "is becoming less applicable in postmodernity" because of a lack of "a coherent dominant culture against which a subculture can express its resistance" (48). In the postmodern world, subcultural style will no longer be structured around "relations of class. gender or ethnicity" as it was in the past; instead, it will be "constituted through consumption" (Muggleton 48). For Muggleton, the products that you consume and display are no longer simply reflective or expressive of your social status or identity and its relationship to the mainstream or dominant culture; rather, the acquisition and ownership of specific consumer goods has become fundamental in the identity formation process. The first fashion story in Deeply Superficial, titled "Same Same, But Different," explores how youth internationally all 
dress rather similarly despite thinking that their appearance is unique and somehow expressive of their personality and place in the world. These pictures of well-dressed young women were taken with this project in mind in public spaces during a trip to Southeast Asia in December of 2006 and in Toronto during March of 2007, and then later reorganized on the page in trenddictated clusters.

In the foreword of Nylon Magazine's Street: The Nylon Book of Global Style, Editor in Chief Marvin Scott Jarrett writes, "Each place I've visited has a totally different look, and l've realized how much what people are wearing tells you about a city and its culture" (6). In fact, the premise of the book is that "As the world gets smaller and cultures intermingle, options for personal expression multiply exponentially" (Nylon Magazine 8). Moreover, the editors wanted to showcase the most original and stunning expressions of fashionable dress they've encountered over the years. I would argue, in fact, that this is a misleading premise because most of the individuals shown in Street and "Same Same, But Different" appear as simply variations on a theme rather than unique individuals. As Josef Hoffmann points out in his 1898 essay "The Individual Dress": "It is astonishing that at a time when one wants to be absolutely original and remarkable, in fact very few people are really original" (122). The dilemma is that although for many individuals today fashion has "a complex relationship to identity" and is considered an intimate form of self-expression, the reality is that "the clothes we choose to wear [simply] represent a compromise between the demands of the social world, the milieu in which we belong, and our individual desires" (Entwistle 114). Entwistle draws these observations from the fashion theories of sociologist Georg Simmel, who writes in "On Fashion" that "Two social tendencies are essential to the establishment of fashion, namely, the need of union on the one hand and the need of isolation on the other. Should one of these be absent, fashion will not be formed-its sway will abruptly end" (294). Fashion, therefore, can only exist in societies that allow their members to make clothing choices, rather than adhering to strict customs or uniform 
rules of dress. At the same time, both between and within societies fashion is used to connect individuals and signify their similarity to each other, and emphasize their difference from others. Ultimately, our clothing choices are more a "subtle balancing act between conformity and differentiation" than a true expression of identity or personality (Cameron 179), because in practice "fashion fulfills a double, contradictory purpose for consumers: to be both the same and different from everyone else" (Mandoki 615).

Furthermore, thanks to the advance of technology and the global production and distribution of fashion imagery and goods, trends are spreading worldwide faster than ever, and the same clothes may be sold throughout the world by any number of mass-market retailers. As Daniel Purdy points out:

The first commentators on mass culture were fascinated and appalled by the conformity of modern fashion, particularly because it was combined with a rapid turnover in styles. How could hundreds of thousands, if not millions, of people all come to the same aesthetic conclusion in a matter of months? (12)

Similarly, Andrew Hill notes that instead of "living in an era of remarkable sartorial expressiveness, richness and heterogeneity" in fashion, we live in a time where most people dress rather similarly (67). In an essay entitled "People Dress so Badly Nowadays: Fashion and Late Modernity," he laments how when he walks down Oxford Street in London all of the shops appear "piled high with the same things... offering something new and the same to everyone" despite the contemporary emphasis on identity formation and self-expression through fashion consumption (70). "Same, Same But Different" is an attempt to address this lack of real choice within the fashion system, and the paucity of individual expression through dress.

The second feature in Deeply Superficial, "Logomania," was inspired by a reading of Thorstein Veblen's theory of conspicuous consumption in Theory of the Leisure Class, which examines the rise and habits of the new bourgeoisie in $19^{\text {th }}$ century America. The idea of 'fashion' itself, as opposed to dress or costume, has only emerged "within a particular kind of 
society, one where social mobility is possible" because historically fashion has developed "during the movement towards a capitalist society and the emergence of a bourgeois class" as a tool for social differentiation (Entwistle 44). Ultimately, then, fashion "suggests competitive emulation, a rank-order tournament in which the prize is social distinction" (Caves 182). Veblen's theory fits with this notion of the role of fashion, stating that the "[c]onspicuous consumption of valuable goods is a means of reputability to the gentleman of leisure," especially in an age when many live in cities and cannot easily express their wealth through more traditional means (56). Now that individuals are exposed "to the observation of many persons who have no other means of judging of [one's] reputability than the display of goods (and perhaps of breeding) which [one] is able to make while... under their direct observation", it is more important than ever to use one's means to acquire and display conspicuously one's "worth" (Veblen 64). Furthermore, the outward display of material goods is important since within "modern civilized communities the lines of demarcation between social classes have grown vague and transient" and dress is a way for individuals to strive towards "the next higher stratum" socially (Veblen 62).

The idea that women should be dressed to put "in evidence their master's ability to pay" (Veblen 133) and "represent [their husband's] wealth in the opulence of her clothes" (Vinken 5) is less dominant today. However, Veblen's theory of using dress to conspicuously denote your (desired) social worth is still highly relevant in the early $21^{\text {st }}$ century, especially through the use of brands and logos. While Veblen refers to elegant dress and expensive materials as a way of showing your wealth in Theory of the Leisure Class, with the rise of branding in the $20^{\text {th }}$ century logos have become the new "insignia of leisure" (Veblen 125). Today, most commodities are "desired and acquired" for their status value or exchange value rather than their direct use value (Milner 172), and "consumed not because they ostensibly satisfy some practical need but because they serve as ways of differentiating individuals within the social hierarchy" (Negrin 113). This relates back to Simmel's theory of fashion as a unifying and distinguishing social 
force. One's fashion goods no longer need to be well-made or sumptuous in material to be conspicuous -simply wearing expensive designer or branded merchandise communicates the same message.

The "Logomania" editorial features collages of digital and film images and scanned Polaroid pictures of a plethora of fashion accessories, so chosen because they most conspicuously display logos in the high-end market and are one of the most profitable segments for fashion brands today. In fact, the profit margins for accessories are higher than those for apparel, and "accessories provide the lion's share of sales and profit for fashion heavyweights" in the high-end market (Rohwedder B1). Culled from my closet and the street vendors of Vietnam ${ }^{8}$, the accessories shown include both "real" and "fake" items representing a wide range of designer brands and displaying very recognizable logos. The story has three objectives: to show both the emptiness of and meaning imbued within the sign (logo) in contemporary capitalist culture, which so often fetishizes these branded fashion products; to explore the real problem of counterfeits for both consumers and producers within fashion; and to point out how the medium of fashion photography flattens the difference between the authentic and the other, because differences such as finishing touches and materials simply do not "read" in print.

Of course, the construction, design and marketing of an authentic Louis Vuitton bag is much costlier and more desirable than that of its counterfeit. Aside from being illegal, counterfeit fashion items are socially stigmatized in our culture, and "a tag of authenticity is a powerful force in selling goods" (Jenß 387). However, what about the fact that the presence of fakes make the real items even more socially desirable, offering the authentic owner the envy of others? And would there be any difference between an "authentic" Marc Jacobs elastic band and a "counterfeit" one? In such an instance, the fashion product with a logo only differs from one

\footnotetext{
${ }^{3}$ Because most designer accessories are final sale or very expensive (and therefore risky) to acquire and return, for this story I photographed items a selection of items that I already owned. I was careful, when making these selections and purchasing the counterfeit pieces, to include a representative variety of brands and product categories.
} 
without in price and not quality, detail, or originality. In fact, theorists such as Michel Pastoureau have argued that "the concepts of falsity and authenticity are cultural constructs" (Jones 7 ), and "Logomania" is an attempt to put the value and notion of branding and authenticity to the test. And what does it mean to be a fake when "several of the most prestigious 'made in Italy' brands are in reality, entirely manufactured in China" and made in the same factories as the counterfeit but with different materials (Reinach 49)?

According to Heike Jenß, while the word 'authenticity' has Greek and Latin roots and was used "in juristic contexts" for many centuries, it only became an important concept in the nineteenth century when "new possibilities of copying, serial production, and mechanical reproduction" were introduced to the arts and crafts as well as the production of objects at large (394-5). Specifically, "with the advent of mechanical reproduction... art had lost its ritual and symbolic uses" and therefore its cultural importance and financial value had to be reconsidered using new criteria (Blythe 146), since "mass replication via modern manufacturing methods undermines the whole value-structure of the fine arts" (Walker 73). The third of the five fashion editorials was inspired by the issues of authenticity expressed in Walter Benjamin's seminal 1936 essay "The Work of Art in the Age of Mechanical Reproduction." Although Benjamin's thesis for the essay was really about politicizing aesthetics to overthrow facism (or 'the totalitarian state') with socialism (or 'the constructive forces of humanity'), for the purposes of this project I am much more interested in his discussion of the "aura" of an original work of art, and the essential differences between manual and mechanical reproduction. Within the business of fashion, these issues have become increasingly important and controversial, and Benjamin's theory provides an interesting facet through which I can examine the role of authenticity in design and profitability.

In the essay, Benjamin points out that when a work of art is reproduced en masse, its originality ceases to matter since each work is the same and "every work is now replaceable"

\footnotetext{
${ }^{9}$ First published in 1936 in the French translation of Zeitschrift für Sozialforschumg (Wolin 183).
} 
(Wolin 188); therefore, he asks, how can the work of art command the same cult or ritual importance as it used to? Instead, its new function lies in its 'exhibition value.' Benjamin explains, "From a photographic negative... one can make any number of prints; to ask for the "authentic" print makes no sense. But the instant the criterion of authenticity ceases to be applicable to artistic production, the total function of art is reversed." (225-226) In principle, all artworks have "always been reproducible," the important difference is that now they are mechanically rather than manually reproduced (Benjamin 220). Faster and more affordable to produce, a "technical reproduction can put the copy of the original into situations which would be out of reach for the original itself," changing the way that one interacts with artwork (Benjamin 222). Ultimately, Benjamin believes that even a perfect reproduction of an artwork lacks what he describes as "its presence in time and space" (222). Accordingly, what "withers" is "the aura of the work of art," or its authority (Benjamin 223).

Of course, the situation has become much more complicated with the rise of postmodernity, what W.J.T. Mitchell calls 'the pictorial turn' in his 1994 essay "What Do Pictures 'Really' Want," and the advent of digital reproduction and the computer in the last two decades, where there is never a discernible difference between the 'original' and the 'copy' except that one was created earlier in time. Director Wim Wenders explores this issue briefly in his 1989 film starring the designer Yohji Yamamoto, Notebook on Cities \& Clothes, although the central theme of the film was identity:

With painting, everything was simple. The original was unique, and each copy was a copy. With photography and then film it began to get complicated. The original was a negative. Without a print, it did not exist. It was just a negative. The copy was the original. But now, with the electronic and soon the digital image, there is no more negative and no more positive. The very notion of "the original" is obsolete. Everything is copy. All distinction is arbitrary. 
Commissioned by the Centre George Pompidou, the film focuses on the fitting themes of authenticity and reproduction, which have been important problems and concepts within contemporary fashion design (Vinken 71). As Baudrillard points out in his chapter on "Models and Series" in The System of Objects, the perception at least is that for "clothing styles the pace of change is very rapid, and the office workers of today wear dresses derived from last season's haute couture models" (164).

In "Last Season's Designer Clothes," the purpose is to photograph mass-market pieces that are trendy, well-made, and bona fide knock-offs of high-end designer clothing and accessories. The garments featured are also examples of "fast-fashion," which has "a shortened cycle from design to finished product" and tries to "beg, steal and borrow ideas from the highfashion runways". in order to appeal to the consumer (Frazier 6). This fast fashion system beautifully serve the needs of capitalism, encouraging ever-increasing cycles of consumption through the acquisition of multiple, similar goods. The only indication that these are not the "real" designer goods comes from the text in the caption, which indicates the brand or designer that has been copied as well as where the garment is actually from. When modern fashion was "born symbolically with [designer Charles] Worth in the mid-1800s," issues of authenticity were irrelevant because everyone who could afford to wear the latest fashions had them made custom by local dressmakers (Reinach 47). Although ideas could be "borrowed," each garment was necessarily unique in cut, fit, and materials. But when clothes started to be mass-produced, garments became models that could be "exactly reproduced at will". rather than unique articles of clothing (Vinken 20). Because clothing today is more disposable, and distinguishing factors such as material, fit, cut, and construction matter less in the context of rapidly changing trends. design has become the primary distinction between designer and mass fashion. Originality, within this system, is a privileged and valuable commodity.

By employing traditional fashion poses and settings, the editorial emulates the aesthetic of normative high-fashion photo shoots while subverting the content. What is interesting is that it 
is possible to appreciate the photo shoot without knowing the original garments, or knowing that you like the fashion goods primarily because you have seen them everywhere before. "Last Season's Designer Clothes" questions notions of authenticity and originality in fashion while admitting the futility of intellectual property rights with regards to designer knock-offs ${ }^{10}$. The problem is that with contemporary fashion, at least along the traditional 'high' and 'low' divide, "the series offers the immense majority of people a restricted range of choices, while a tiny minority enjoy access to the model and its infinite nuances" (Baudrillard 161). If one could apply Baudrillard's "Models and Series" to contemporary fashion, fast-fashion would be an example of the 'series' while couture would be equivalent to what he calls 'the model'. It seems that in contemporary Western societies, with the obsession for the latest and greatest, in reality most fashion changes involve minor and superficial alterations rather than true innovation, especially within the fast-fashion category which does not "invest in design-but are rather inspired by the prêt à porter fashion shows, which they simplify" (Reinach 48).

True innovation is also subservient to superficial change in "The Modern Uniform," which features variations on a theme -the contemporary urban uniform of denim jeans and a knit t-shirt-in order to illustrate an understanding of the role of "anti-fashion" within the fashion system. In his influential book Fashion \& Anti-Fashion, Polhemus argues that dress or adornment -"all of the things people do to or put on to their bodies in order to make the human form, in their eyes, more attractive"(9)-is different than 'fashion', which "is not simply a change of styles of dress and adornment, but rather a systematic, structured and deliberate pattern of style change" (15). Informed by Johann Carl Flügel's The Psychology of Clothes, Polhemus argues that 'fashion' exists in contrast to 'anti-fashion', a category which includes fixed costume that "changes slowly in time [but]...varies greatly in space" and "reflect and express fixed, unchanging, rigid social environments" rather than a concern with social mobility and constant

\footnotetext{
${ }^{10}$ While counterfeiting-to produce or sell a fake branded item-is illegal in many countries including France, knock-offs are hard to prove in court and are not normally illegal.
} 
change $(12,14)$. With globalization, however, dress trends rarely remain localized, a problem which "Same Same, But Different" explores. While Polhemus refers to traditional folk costumes and the plundering of traditional dress for the service of fashion trends in his analysis of antifashion, "The Modern Uniform" is more interested in how fashionable garments such as jeans and t-shirts have now gained the anti-fashion signifier of constancy while constantly being tweaked according to the demands of fashion change. Since their inception and rise to popularity, these apparel items remain inherently unchanged even as more superficial qualities such the materials or fit or colours might be altered seasonally. Although these clothes exist as part of the fashion system, they change very little over time and function almost as modern uniforms, embracing the "anti-fashion impulse of continuity" (Entwistle 50).

As Elizabeth Wilson writes in "Fashion in Modernity," while constant fashion change and the existence of a plethora of brands and styles have become normative characteristics of fashion today, in practice "the end result is [very] uniform and in any case does nothing to dislodge the pre-existing uniform of jeans, combats (or similar), trainers and fleeces" (13). "The Modern Uniform" speaks to both the uselessness of the constant change within our fashion system (besides for capitalist growth and corporate profits), and the design genius of these two clothing staples. Oscar Wilde once farnously called fashion "a form of ugliness so intolerable that we have to alter it every six months" (qtd. in Stern 8). Jeans and t-shirts, in contrast, fulfill our sartorial needs so well that they are always in fashion and require very little alteration from one season to the next. In fact, the famed French fashion designer Yves Saint Laurent once said, "I wish I had invented blue jeans... They have expression, modesty, sex appeal, simplicity-all I hope for in all my clothes" (qtd. in Sullivan 5). Since Levi Strauss \& Co. patented therr blue jean prototype in 1873 , very little has changed from the original design, and it has been argued that worldwide "blue jeans have obliterated every demographic distinction-age, ethnicity, income, education-[and have became] the common casual uniform" (Sullivan 5). A secondary theme which "The Modern Uniform" explores is the importance of branding 
- and strategic pricing in a fashion system inundated with products that are all quite similar. The garments shown were purposefully chosen from different retail price points, ranging from the mid-priced urban line FCUK to pieces from discount department store Zellers' private label, Cherokee. Looking at the images, the price differences are not really justified by factors such as design, material or construction as much as the brand of each t-shirt and pair of jeans." Especially for staple garments ${ }^{12}$ that differ little in material and construction from one garment to another, the price ranges seemed rather broad and it was interesting to see how much a difference styling and propping made to the actual appearance of the garment in print.

The final story for this magazine prototype, "History Now," celebrates and deconstructs fashion within postmodernity. In Consumer Culture and Postmodernism, Mike Featherstone explains that the term 'postmodernism' was first used as early as 1934 by Federico de Onis to refer to a reaction against modernism, but it was not until 1947 that Toynbee used 'postmodernity' to indicate a new stylistic period within history (Featherstone 30). Both terms are contested, mired in complexity and have specific connotations depending on the fieid of study. For example. while Featherstone believes that the term rose to prominence in the 1960s, the British author and architect Charles Jencks believes that it was the dynamited fall of the PruttIgoe housing development in St. Louis in July of 1972 which symbolically marks the end of modernism within the realm of architecture (Harvey 375 ). Harvey associates postmodernism with an acceptance of empherality, fragmentation, discontinuity (380) and Lyotard's "incredulity towards metanarratives'" (qtd. in Harvey 381). Moore characterizes postmodernism with selfreflexivity, the use of stylistic quotations, the coilapse of "highbrow" and "lowbrow" culturai boundaries, and a flattening of history and effect (305). Essentially, postmodernism contrasts greatly from the "functional rationality" (Muggleton 38) and aspirations towards "universal human

\footnotetext{
"Fit was a differentiating factor, however, as the lowest priced brands were sized larger and did not fit the model as well as garments from the more fashion-forward brands.

${ }^{12}$ Basic staples such as jeans and t-shirts are apparel items that change very little in design from season to season. and that many people are likely to own multiples of.
} 
emancipation" (Harvey 377) characteristic of modernism, which was inspired by the legacy of the Enlightenment. Its rise has lead to significant social and cultural changes, including the way we understand truth and beauty.

The application of postmodern aesthetics to the arts, particularly with regards to fashion and consumption, is a process which is both fascinating and problematic. According to Baudrillard, we live in a "post-industrial" world "in which the world of production has given way to the world of consumption and of the spectacle;" for him, fashion "represents the triumph of the artificial" in this world where "the cult of appearances is all important" (Negrin 112-114). Muggleton describes fashion in postmodernity as "aesthetic play, with [a] focus on hedonism, pleasure and spectacle, 'a return to ornament, decoration and stylistic eclecticism'" (38). Furthermore, the contemporary emphasis on ever-shorter cycles of production and consumption means that fashion now relies on individualistic applications of "postmodernist codes" rather than structured "modernist styles" that were dictated by fashion arbiters and designers (Muggleton 39).

This "proliferation and fragmentation of style" has encouraged individuals to reassemble, blend and juxtapose clothing styles and eras at will (Muggleton 44). While this offers individuals an opportunity to express themselves through dress and a fashion, it has also resulted in a cultural "fascination with nostalgia" and the meaningless plundering of past styles by designers eager to produce a "non-stop fashion parade" (Muggleton 45). As pointed out in Stuart and Elizabeth Ewen's 1982 Channels of Desire: 'Today there is no fashion: there are only fashions.' 'No rules, only choices.' 'Everyone can be anyone'" (Qtd. in Featherstone 83).

"History Now" shows an assortment of new and vintage clothing and accessories that exemplify the stereotypes of popular fashions for each of the last four decades, with an apparent "insubstantiality with regard to linear historical progress" (Lehmann, "Benjamin" 201). In print, it is hard to tell which pieces are vintage and which are simply retro, and, in any case, Helke Jenß's work in the area of "retro youth cultures" has shown that the styles that are 
commonly associated with a decade are more often than not just "stereotypical," presenting a "hyper-version of the decade past" that has been filtered through images and the media rather than an accurate portrayal of historical dress (392). Essentially, explains Jenß, "In the process of 'authentic reproduction,' consciously or not, the past becomes adapted to the present" and the idea of what is authentic shifts to accommodate new needs and demands (394). This is rather ironic, considering the constant revivalism which plagues contemporary fashion and the rising importance of 'authenticity' as a marketing tool. The 1970's 'punk' plaid shirt featured in "History Now," for one, is just another part of "selectable ensembles, which can be appropriated and performed, dislocated from a former 'original' cultural context and meaning" (Jenß 395). Its material, fit and purpose differs greatly from when it was first worn as part of the uniform of rebellious youth, and from when it appeared on the Perry Ellis catwalk in the 1990's as part of Marc Jacobs' infamous 'grunge' collection. What results, then, is what Morris calls "a certain loss of history" (8). Vintage and historically-inspired clothing is worn without an appreciation of the context in which the original designs were made and popularized, and historical perspective is lost within revivalism and reinvention.

Through its exploration of the most relevant themes and controversial debates within fashion theory today using the fashion magazine format, Deeply Superficial is uniquely able to contribute to the existing literature on the fashion magazine genre. By outwardly following the format of fashion magazines, yet subverting the prevailing ideology of consumption through thematic and textual decisions, the project exposes the rigidity of the genre's conventions and limitations through example. Prior research by theorists such as Diane Crane and Brian Moeran has demonstrated that the fashion publishing industry is controlled by numerous "competing forces - both within the fashion world itself (fashion editor, stylist, art director and photographer) and between the interests of readers, on the one hand, and those of a magazine's advertisers, on the other" (Moeran 734). Despite all conversations about fashion photography as art, there are many real limitations to what can and is included: 
Working for a magazine involves the loss of control. The artistic objectives of the photographer and the commercial needs of the magazine are never the same... It is pointless to argue whether personal work is better or worse than editorial work; the truth is it is just different. (Kismaric 134)

This difference is what makes the "Beyond Commerce" project compelling, as a personal attempt at editorial work. The resulting magazine serves as a demonstration of the drawbacks and strengths of the fashion magazine genre. The images are beautiful and could stand up to a critique with or without the background theory to support them, and there is a sense of flow and cohesion to the stories. It seems, however, that Deeply Superficial reads as a commercial project, not aesthetically dissimilar to an advertising-funded consumer publication, despite the fact that it was not intended to sell fashion goods but rather critique the weaknesses of the contemporary fashion system. Even as an "art" publication, the images in Deeply Superficial seem fairly attached to the fashion world -and appear more as a celebration of its aesthetic joys than a separation from it. Furthermore, the project illustrates the inability of the fashion photograph to convey meaning and a narrative outside of that which the accompanying text reveals, especially when the visual appeal of an image will not be compromised in favour of greater narrative coherence. While literal or stereotypical translations of the themes were avoided, perhaps more props or better set-design would have alleviated this problem to some degree.

Nevertheless, "Beyond Commerce" is a complex and hands-on educational endeavor, attempting with some success to deconstruct the components and conventions of a fashion magazine. Although the project is not intended for a professional audience, but rather an academic one, its explorations of theory and commerce have relevant implications in both spheres. Instead of creating editorials based on a concept as vague and shallow as "Bright Colours" or "Wide Legged Pants," Deeply Superficial drew inspiration from issues central to the contemporary fashion industry, such as authenticity, creativity, consumer culture, and 
globalization. The results showcase both the strengths of the fashion editorial and the limitations of how much (and what) it can convey.

Exploring the mechanical and cultural constructions of the fashion magazine outside of the constraints of advertising, Deeply Superficial visually explores our relationship to dress from a theoretical and creative standpoint. Ultimately, it exposes the commercial nature of the genre and narrative shortcomings, but reveals also that its boundaries stand to benefit from being pushed further beyond the norm. Fashion magazines, because they take the form of a highly visual medium intended to showcase rather than consider or deconstruct apparel and accessories, are a poor medium with which to present theoretical concepts. What I discovered is that the rigid conventions of the genre, as well as its reliance on visual appeal and a userfriendly interface, create restrictions on the depth of ideas that could be communicated. In many cases, such as in the Walter Benjamin-inspired story, the meaning that I tried to embed within the editorial through the selection of clothing, hair and make-up styling, and use of props and location was mostly lost along the way. Some ideas simply did not photograph well or clearly, and others were too literal in their expression of the theme and had to be edited. The more conceptual and abstract theories were the most difficult to translate visually, and oversimplification threatened several features in the magazines.

"Beyond Commerce" was an exercise to see how far the fashion magazine's conventions and contents coyld be extended, pushing and at once recontextualizing the normative themes and foci of fashion editorials. However, from the project I also learned that these boundaries exist for practical and logistical reasons, including the need to collaborate with others and alter your creative concept based on issues such as access and funding. This pragmatic understanding of this cultural medium as a business enterprise that provides specific services to its audience provides a valuable starting point in considering the genre as a whole. While l've discovered is that theory and intellectual debate may not be the answer, the it is clear that the genre's rigid conventions would benefit from a reconsideration and redesign. Early $21^{\text {st }}$ 
century Western society is marked by an age when magazine readership is in decline, information is more readily gleaned from the Internet, and media analysts are saying that "like it or not, publishers must increasingly tie their fortunes to the Web" (Granatstein 52) and that "paper media today are... still dominant but enjoying their last hurrah" because in fact "it's late in the magazine era" (Powers 66). Ultimately, in order to survive, fashion magazines have to find new ways to remain relevant to their readers' lives, whether it is simply by recognizing that the same old content formulas are getting stale. Beyond Commerce was an exploration into the commercial heart and intellectual possibilities inherent in the genre, and while its results are less than optimistic, they provide an interesting counterpoint to what formulaic nature of much contemporary fashion publishing. As a business, fashion magazines serve a distinctive cultural and economic role, but that is not to say that there is not room for change and conceptual shifts. 


\section{Bibliography}

"About the Programme." Communication and Culture Program. York University. 17 March 2007 $<$ http://comcult.yorku.ca/s.

Angeletti, Norberto. In Vogue: The lllustrated History of the World's Most Famous Fashion Magazine. New York: Rizzoli, 2006.

Aoki, Shoichi. Fruits. New York: Phaidon, 2001.

Ball, Michael S., and Gregory W. H. Smith. Analyzing Visual Data. Newbury Park, CA: Sage Publications, 1992.

Barnard, Malcolm. Fashion as Communication. $2^{\text {nd }}$ ed. New York: Routledge, 2002.

Baudrillard, Jean. "Models and Series." The System of Obiects. New York: Verso, 2005. 147168.

Bellafante, Ginia. "Art That Wears $\$ 780$ Shoes." New York Times 11 April 2004, Late east coast ed.: 2.1 .

Belson, Al. Fashion Photography Techniques. New York: Amphoto, 1970.

Benjamin, Walter. "The Work of Art in the Age of Mechanical Reproduction." Illuminations. Ed. Hannah Arendt. New York: Schocken Books, 1968. 218-251.

Berger, Arthur Asa. Seeing is Believing: An Introduction to Visual Communication. 2nd ed. Mountain View, CA: Mayfield, 1998.

Berger, John. Ways of Seeing. London: Penguin Books, 1972.

Blythe, Mark. "The Work of Art in the Age of Digital Reproduction: The Significance of the Creative Industries." International Journal of Art \& Design Education 20.2 (2001): 144150.

Botello, Chris. Adobe InDesign CS2 Revealed. Boston, MA: Thomson Course Technology, 2006.

Breward, Christopher. The Culture of Fashion: A New History of Fashionable Dress. New York: St. Martin's Press, 1995. 
Breward, Christopher, and Caroline Evans, eds. Fashion and Modernity. New York: Berg, 2005. Burn, Andrew, and David Parker. Analyzing Media Texts. New York: Continuum Books, 2003. Cambridge, MA: Harvard University Press.

Cameron, Don. "Off-the-Rack Identities: Japanese Street Fashion Magazines and the Commodification of Style." Japanese Studies, 20.2 (2000): 179-187.

Casselman, Sarah. Personal interview. 26 Mar. 2007.

Caves, Richard. Creative Indu stries: Contracts between Art and Commerce. Cambridge, MA: Harvard University Press, 2000.

Celant, Germano, ed. Art/Fashion. New York: Distributed Art Publishers, 1997.

Chang, Angel. "Exhibition Review: Fashioning Fiction in Photography since 1990." Fashion Theory 9.3 (2005): $361-368$.

Coles, Alex. DesignArt: On Art's Romance with Design. New York: Harry Abrams Inc., 2005. Connor, Steven. "Postmodernities." Postmodernist Culture: An Introduction to Theories of the Contemporary. 2nd ed. Cambridge, MA: Blackwell Publishers, 1997. 27-64.

Craik, Jennifer. "Soft focus: Techniques of Fashion Photography." The Face of Fashion: Cultural Studies in Fashion. New York: Routledge, 1994. 92-114.

Crane, Diana. "Fashion Images and the Struggle for Women's Identity." Fashion and its Social Agendas: Class, Gender, and Identity in Clothing. Chicago: University of Chicago Press, 2000. 202-234.

---. "Gender and Hegemony in Fashion Magazines: Women's Interpretations of Fashion Photographs." The Sociological Quarterly 40.4 (1999): 541-563.

Currie, Dawn. Girl Talk: Adolescent Magazines and their Readers. Toronto: University of Toronto Press, 1999.

-.-. "Going Green': Mythologies of Consumption in Adolescent Magazines." Youth \& Society 26.1 (1994): 92-117.

Dabbs, Alistair et al. InDesign Essentials. Lewes: llex Press, 2006. 
De la Hay, Angela. "Vogue and the V\&A Vitrine." Fashion Theory 10.1 (2006): 127-152.

Entwistle, Joanne. The Fashioned Body: Fashion, Dress and Modern Social Theory. Malden, MA: Polity Press, 2000.

Featherstone, Mike. Consumer Culture and Postmodernism. Newbury Park, CA: Sage Publications, 1991.

Finkelstein, Joanne. After a Fashion. Melbourne: Melbourne University Press, 1996.

Forbes, Nicole. Personal interview. 28 Feb. 2007.

Frazier, Mya. "The Latest European Import: Fast Fashion." Advertising Age 77.2 (2006): 6.

Gatter, Mark. Software Essentials for Graphic Designers. New Haven, CT: Yale University

Press, 2006.

Goethe, Johann Wolfgang. "On Art and Craftwork." The Rise of Fashion. Ed. Daniel Leonhard Purdy. Minneapolis: University of Minnesota Press, 2004. 139-144.

Granatstein, Lisa. "The Bermuda Triangle." Media Week 30 October 2000: 52-53.

Grappa, Carol Di, ed. Fashion: Theory. New York: Lustrum Press, 1980.

Guba, Egon G., and Yvonna S. Lincoln. "Competing Paradigms in Qualitative Research." The Landscape of Qualitative Research: Theories and Issues. Ed. Norman K. Denzin and Yvonna S. Lincoln. Thousand Oaks, CA: Sage Publications, 1998.

Hammer, Dean and Aaron Wildavsky. "The Open-Ended, Semistructured Interview: An (Almost) Operational Guide." Craftways: On the Organization of Scholarly Work. New Brunswick, NJ: Transaction, 1989. 57-101.

Harvey, David. The Condition of Postmodernity: An Enquiry into the Origins of Cultural Change.

Cambridge, MA: Blackwell Publishers, 1989.

Hegel, Georg W. F. "On Drapery." The Rise of Fashion. Ed. Daniel Leonhard Purdy.

Minneapolis: University of Minnesota Press, 2004. 145-152.

Hill, Andrew. "People Dress so Badly Nowadays: Fashion and Late Modernity." Fashion and Modernity. Ed. Christopher Breward and Caroline Evans. New York: Berg, 2005. 67-78. 
Hoffmann, Josef. "The Individual Dress (Das individuelle Kleid)." Against Fashion: Clothing as Art, 1850-1930. Ed. Radu Stern. Cambridge, MA: MIT Press, 2004. 122-124.

Horyn, Cathy. "Fashion and Art Embrace, if Not Passionately." The New York Times 5 August 2003, Late ed.: B8.

Jenß, Heike. "Dressed in History: Retro Styles and the Construction of Authenticity in Youth Culture." Fashion Theory 8.4 (2004): 387-404.

Finkelstein, Joanne. After a Fashion. Melbourne: Melbourne University Press, 1996.

Jobling, Paul. Fashion Spreads: Word and Image in Fashion Photography since 1980. New York: Berg, 1999.

Johnson, Janet Buttolph, and H. T. Reynolds. "Research Design." Political Science Research Methods. $5^{\text {th }}$ ed. Washington, DC: CQ Press, 2005. 49-102.

Johnson, Richard, et al. The Practice of Cultural Studies. Thousand Oaks, CA: Sage Publications, 2004.

Jones, Mark. "Do Fakes Matter?" Why Fakes Matter. Essays on Problems of Authenticity. Ed Mark Jones. London: British Museum Press, 1992. 7-12.

Kelby, Scott. InDesign CS Killer Tips. Ed. Scott Kelby and Terry White. Indianapolis, IN: Peachpit Press, 2004.

Kezar, Adrianna. "Transformational Elite Interviews: Principles and Problems." Qualitative Inquiry, 9.3 (2003): 395-415.

Kismaric, Susan. Fashioning Fiction in Photography since 1990. Ed. Eva Respini and Museum of Modern Art. New York: Museum of Modern Art, 2004.

Kolonia, Peter. "Fashion Photographer?" Popular Photography \& Imaging 69.4 (2005): $70-74$. Lehmann, Ulrich. "Benjamin and the Revolution of Fashion in Modernity." Tigersprung: Fashion in Modernity. Cambridge, MA: MIT Press, 2000. 199-278. 
Lehmann, Ulrich. "Fashion Photography." Chic Clicks: Commerce and Creativity in

Contemporary Fashion Photography. Ed. Gilles Lipovetsky, Ulrich Lehmann, and Fotomuseum Winterthur. New York: Institute of Contemporary Art, 2002. 12-18.

Leventon, Melissa. Artwear: Fashion and Anti-fashion. London: Thames \& Hudson, 2005.

Lilleker, Darren G. "Interviewing the Political Elite: Navigating a Potential Minefield." Politics 23.3 (2003): 207-214.

Lipovetsky, Gilles. "More Than Fashion." Chic Clicks: Commerce and Creativity in

Contemporary Fashion Photography. Ed. Gilles Lipovetsky, Ulrich Lehmann, and

Fotomuseum Winterthur. New York: Institute of Contemporary Art, 2002. 8-11.

Lipovetsky, Gilles, Ulrich Lehmann, and Fotomuseum Winterthur, eds. Chic Clicks: Commerce and Creativity in Contemporary Fashion Photography. New York: Institute of Contemporary Art, 2002.

Mackrell, Alice. Art and Fashion. London: Batsford, 2005.

Mallarmé, Stéphane. Mallarmé on Fashion: A Translation of the Fashion Magazine La Dernière Mode with Commentary. Trans. P.N. Furbank and Alex Cain. New York: Berg, 2004. Mandoki, Katya. "Point and Line Over the Body: Social Imaginaries Underlying the Logic of Fashion." Journal of Popular Culture. 36.3 (2003): 600-623.

Milkie, Melissa A. "Contested Images of Femininity: An Analysis of Cultural Gatekeepers' Struggles with the :Real Girl' Critique." Gender and Society 16.6 (2002): 839-859.

Millard, Rosie. "Overexposure." New Statesman 135.4782 (2006): 40-42.

Miner, Murray. Freaks, Geeks, and Cool Kids: American Teenagers, Schools, and the Culture of Consumption. New York: Routledge, 2004.

W. J. T. Mitchell. "What Do Pictures 'Really' Want?" October 77 (1996): 71-82.

Moeran, Brian. "More Than Just a Fashion Magazine.". Current Sociology 54.5 (2006): 725-744. Moore, Ryan. "Postmodernism and Punk Subculture: Cultures of Authenticity and Deconstruction." Communication Review 7.3 (2004): 305-327. 
Morris, Martin. "Contradictions of Postmodern Consumerism and Resistance." Studies in Political Economy 64 (2001): 7-32.

Moser, Horst. Surprise Me: Editorial Design. New York: Mark Batty, 2003.

Muggleton, David. Inside Subculture: The Postmodern Meaning of Style. New York: Berg, 2000. Müller, Florence. Art \& Fashion. London: Thames \& Hudson, 2000.

Negrin, Llewellyn. "The Self as Image: A Critical Appraisal of Postmodern Theories of Fashion." Theory Culture \& Society 16.3 (1999): 99-118.

Notebook on Cities \& Clothes. Dir. Wim Wenders. Perf. Yohji Yamamoto. DVD. Road Movies, 1989.

Nylon Magazine. Street: The Nylon Book of Global Style. New York: Universe, 2006.

Owen, William. Modern Magazine Design. Dubuque, IA: Wm. C. Brown, 1992.

Parr, Martin. Fashion Magazine. London: Thames \& Hudson, 2005.

Phillips, Rober. "The Politics of History: Some Methodological and Ethical Dilemmas in Elite-

Based Research." British Educational Research Journal 24.1 (1998): 5-19.

Polhemus, Ted. Fashion \& Anti-Fashion: An Anthropology of Clothing and Adornment. Ed. Lynn

Procter. London, England: Thames and Hudson, 1978.

Powers, William. "Mags Alive." National Journal 28 Jan 2006: 66.

Purdy, Daniel Leonhard. Introduction. The Rise of Fashion: A Reader. Ed. Daniel Leonhard Purdy. Minneapolis, MN: University of Minnesota Press, 2004. 1-12.

Rabine, Leslie W. "A Woman's Two Bodies: Fashion Magazines, Consumerism, and Feminism." On Fashion. Ed. Shari Benstock and Suzanne Ferriss. New Brunswick, NJ: Rutgers University Press, 1994. 59-75.

Ramamurthy, Anandi. "Constructions of Illusions: Photography and Commodity Culture." Photography: A Critical Introduction. $2^{\text {nd }} \mathrm{ed}$. Ed. Liz Wells. London: Routledge, 1996. Reinach, Simona Segre. "China and Italy: Fast Fashion Versus Pret a Porter." Fashion Theory $9.1(2005): 43-56$ 
Rodic, Yvan. Facehunter. 2007. 27 Apr. 2007. 27 Apr. 2007. $<$ http://www.facehunter. blogspot.com>

Rohwedder, Cecile. "Handbag Designer Grips Paris Fashionables." Wall Street Journal 6 Oct 2005, Eastern ed.: B1-B3.

Rose, Gillian. Visual Methodologies. Thousand Oaks, CA: Sage Publications, 2003.

Saad, Michal. Personal interview. 24 Jan. 2007.

Samara, Timothy. Type Style Finder. Gloucester, MA: Rockport Publishers, 2006.

Schuman, Scott. The Sartorialist. 2007. 27 Apr. 2007. 27 Apr. 2007

$<$ http://www thesartorialist. blogspot.com>.

Simmel, Georg. "Fashion." The Rise of Fashion: A Reader. Ed. Daniel Leonhard Purdy. Minneapolis, MN: University of Minnesota Press, 2004. 289-309.

Stein, Sarah R. "Visuality and the image." Journal of Communication 48.2 (1998): 170-177.

Stern, Radu. Against Fashion: Clothing as Art, 1850-1930. Cambridge, MA: MIT Press, 2004.

Stokes, Jane. How to do Media \& Cultural Studies. Thousand Oaks, CA: Sage Publications, 2003.

Sullivan, James. Jeans: A Cultural History of an American Icon. New York: Gotham Books, 2006.

Tank Too. Ed. Masoud Golsorkhi and Andreas Laeufer. London: Thames \& Hudson, 2006.

Tarantino, Chris. Digital Fashion Photography. Ed. Ken Tan. Boston, MA: Thomson Course Technology PTR, 2005.

Taylor, Melissa. "Culture Transition: Fashion's Cultural Dialogue between Commerce and Art." Fashion Theory 9.4 (2005): 445-460.

Taylor, Vanessa. Personal interview. 1 Mar. 2007.

Townsend, Chris. Rapture: Art's Seduction by Fashion since 1970. London: Thames \& Hudson, 2002. 
Veblen, Thorstein. Theory of the Leisure Class. Online: Amazon Press, 2001. 7 Dec. 2005. 5174. http://www. amazon.com/exec/obidos/tg/detail/-/B00005OSET/qid $=1134015937 / \mathrm{sr}=1$ $3 /$ ref $=s r \quad 1 \quad 3 / 104-5894800-2763140 ? v=g l a n c e \& s=e b o o k s$

Vinken, Barbara. Fashion Zeitgeist: Trends and Cycles in the Fashion System. New York: Berg, 2005.

Walker, John Albert. Art in the Age of Mass Media. Boulder, CO: Westview Press, 1994.

Wilson, Elizabeth. "Fashion and Modernity." Fashion and Modernity. Ed. Christopher Breward and Caroline Evans. New York: Berg, 2005. 9-16.

Wimmer, Roger D. and Joseph R. Dominick. Mass Media Research: An Introduction. $8^{\text {th }}$ ed. Toronto: Thomson Nelson, 2006.

Wolin, Richard. Walter Benjamin: an Aesthetic of Redemption. Los Angeles: University of California Press, 1994.

Wollen, Peter. Addressing the Century: 100 Years of Art \& Fashion. Los Angeles: University of California Press, 1999.

Wood, Allan B. The Graphic Designer's Digital Toolkit. $2^{\text {nd }}$ Ed. Clifton Park, NY: Delmar Learning, 2006.

Zahm, Olivier. "On the Marked Change in Fashion Photography." Chic Clicks: Commerce and Creativity in Contemporary Fashion Photography. Ed. Gilles Lipovetsky, Ulrich Lehmann, and Fotomuseum Winterthur. New York: Institute of Contemporary Art, 2002. 28-35. 